\title{
MODALITIES FOR SOIL PREPARATION AND GYPSUM APPLICATION IN ULTISOL: STEM PRODUCTIVITY OF SUGARCANE
}

\author{
RONALDO C. LIMA ${ }^{1}$, LUIZ M. M. DE MELLO ${ }^{2}$, ÉLCIO H. YANO ${ }^{3}$, JOSÉ O. R. DA \\ SILVA ${ }^{4}$, ANDRÉ L. CESARIN ${ }^{4}$
}

\begin{abstract}
The study was conducted in an area of expansion of sugarcane at Vale do Paraná factory in Suzanápolis city - São Paulo (SP), in Brazil, in the northwestern region of the State of São Paulo. It was used the sugarcane variety RB92-5345, 1.5m of spacing between rows, in an Ultisol. The study aimed to evaluate the productivity of sugarcane and first ratoon and some soil chemical attributes in function of soil tillage and application or not of gypsum. The experimental design was randomized blocks with six treatments, in a factorial $3 \times 2$ and six replicates, the main treatments were soil tillage with three equipments, moldboard plow, chisel plow, and heavy harrow, and two secondary treatments with application of $1 \mathrm{t} \mathrm{ha}^{-1}$ of gypsum and no gypsum. After each harvest of cane, the soil was characterized as to its fertility indicators in layers of $0.0-0.15 ; 0.15$ 0.30 and $0.30-0.45 \mathrm{~m}$. Differences in values of soil chemical attributes due to the methods of preparation occurred in the sugarcane did not last until the harvest of the 1st ratoon cane, and also did not influence the crop productivity. The gypsum application resulted in higher values of total recoverable sugar (TRS) and the productivity of tons of stems per hectare (TSH) to sugarcane and 1st ratoon cane, respectively, confirming the initial hypothesis.
\end{abstract}

KEYWORDS: chemical attributes, mechanization, gypsum application, Saccharum spp.

\section{MÉTODOS DE PREPARO DO SOLO E APLICAÇÃO DE GESSO EM ARGISSOLO VERMELHO: PRODUTIVIDADE DE COLMOS DA CANA-DE-AÇÚCAR}

RESUMO: O trabalho foi conduzido em área de expansão de cana-de-açúcar da Usina Vale do Paraná, no município de Suzanápolis - SP, na região do noroeste paulista. Foi utilizada a variedade de cana RB92-5345, espaçamento de 1,5 m entre linhas, em ARGISSOLO VERMELHO. O trabalho objetivou avaliar a produtividade em cana-planta e $1^{\mathrm{a}}$ cana-soca e alguns atributos químicos de solo, em função dos métodos de preparo do solo e aplicação ou não de gesso. $\mathrm{O}$ delineamento experimental utilizado foi o de blocos ao acaso, com seis tratamentos, fatorial $3 \times 2$, e seis repetições. Os tratamentos principais foram preparos de solo com três equipamentos: arado de aivecas, escarificador e grade pesada, e dois tratamentos secundários com aplicação de $1 \mathrm{t} \mathrm{ha}^{-1} \mathrm{de}$ gesso e sem gesso. Após cada colheita da cana, o solo foi caracterizado quanto aos indicadores de fertilidade nas camadas de $0,0-0,15 ; 0,15-0,30$ e 0,30-0,45 m. As diferenças dos atributos químicos do solo, devido aos métodos de preparo ocorridas na cana-planta, não perduraram até a colheita da $1^{a}$ cana-soca e também não influenciaram na produtividade da cultura. A gessagem proporcionou maiores valores de ATR e produtividade de TCH, para cana-planta e $1^{\mathrm{a}}$ cana-soca, respectivamente, confirmando a hipótese inicial.

PALAVRAS-CHAVE: atributos químicos, mecanização, gessagem, Saccharum spp.

\footnotetext{
${ }^{1}$ Eng $^{\circ}$ Agrônomo, Doutor, Programa de Pós-Graduação em Agronomia, UNESP-Ilha Solteira-SP, rclima@ agr.feis.unesp.br.

${ }^{2}$ Professor Titular, DEFERS-FE-UNESP- Ilha Solteira-SP.

${ }^{3}$ Professor Assistente DR, DEFERS-FE-UNESP- Ilha Solteira-SP.

${ }^{4}$ Eng $^{\circ}$ Agrônomo, UNESP-Ilha Solteira-SP.

Recebido pelo Conselho Editorial em: 2-7-2012
}

Aprovado pelo Conselho Editorial em: 30-6-2013 


\section{INTRODUCTION}

The growing demand in the domestic and foreign markets for renewable fuels, especially ethanol, began to attract new investments to the implantation of new areas of sugarcane to meet the industry. According to CONAB (2011), the area under sugarcane grown in Brazil was 8.4 million hectares in 2011, and the state of São Paulo was the main producer, accounting for $52.60 \%$ in acreage and $56.77 \%$ in production. The planting of sugarcane continues to expand in the country and, the states listed with the highest rates of area increase are the states of São Paulo, Mato Grosso do Sul, Goiás and Minas Gerais, respectively.

The inclusion of new regions in the production process of sugarcane requires greater attention to factors of production, including the management and remediation of soils, because it is essential to eliminate physical impairments caused by compacted layers, and as chemical impairments as toxicity by aluminum, acidity and inadequate macronutrient content. The soils of the northwestern region of the state of São Paulo have low $\mathrm{pH}$ and may provide toxicity by $\mathrm{Al}^{3+}$ and/or calcium deficiency, restricting the development of deep roots (CARVALHO et al., 2013). Therefore, the use of agricultural gypsum is presented as a good alternative to improve the structure and nutrient availability in the soil, in the deeper layers, favoring the increase of productivity and longevity of the cane field (RAIJ, 2008).

According to SALVADOR et al. (2010), to select the periodic tillage systems properly, we must take into account the energy demand and soil characteristics, such as texture and moisture. Greater knowledge and domains of these technologies may lead to reduced costs of crop production (KICHLER et al., 2007). Among the different soil preparation equipment, used in the culture of sugarcane, we may highlight the moldboard plows, harrows and chisel plow. Evaluating the energy requirement in different tillage systems based on plowing (disc and moldboard plow), harrowing (heavy and leveling) and scarification in Yellow Red Latosol, SALVADOR et al. (2008) found that scarification had lower energy demand when compared to other tillage systems studied. Evaluating different systems of tillage, MICHEL JUNIOR et al. (1985) achieved a reduction of up to $40 \%$ in energy requirement in scarification when compared to moldboard plow.

Aiming agricultural productivity, it is necessary to determine soil acidity with due correction for the proper performance of the crop, since, according to QUAGGIO (2000), acid soil is essentially deficient due to the small amount of calcium, magnesium, potassium. Therefore, acidic soils may have a chemical barrier in the subsoil, which prevents or hinders the growth of roots. For CARVALHO et. al, (2013), the soils of the northwestern region of São Paulo have low pH and may provide toxicity by $\mathrm{Al}^{3+}$ and/or calcium deficiency, restricting the development of deep roots.

In such cases, in the types of soils that present toxicity by $\mathrm{Al}^{3+}$, the gypsum can stimulate in the crops a greater deep rooting. This action is caused by the increase of levels of calcium and reduction of aluminum saturation. Therefore, the use of agricultural gypsum is presented as a good alternative to improve the structure and nutrient availability in the soil, in the deeper layers, favoring the increase of productivity and longevity of the cane field (RAIJ, 2008).

Due to the importance of these events in the implementation of the cane fields, and considering that the culture of sugarcane is deployed normally in depths between 0.25 and $0.35 \mathrm{~m}$, it is intuitive to think that the tillage with moldboard plows provide better conditions for the development of culture, but as the application of gypsum does not require incorporation, the hypothesis was released that different tillage systems have similar effects on the behavior of the culture, since the soil of the experiment showed no limiting compression. Another hypothesis is that, because it is a soil with low chemical fertility, the use of gypsum provides better conditions in the deeper layers and, thus, higher productivity. This study aimed to: verify the results of different methods of tillage (moldboard plow, heavy harrow and chisel plow), associated with the application or not of gypsum on the chemical attributes of an Ultisol and its effect in productivity and quality of sugarcane. 


\section{MATERIAL AND METHODS}

The experiment was established and conducted between May 2008 and June 2011, in a commercial area of Vale do Paraná factory, in Nova Canaã Paulista city - state of São Paulo (SP), Brazil, in $20^{\circ} 23^{\prime} \mathrm{S}$ and $50^{\circ} 56^{\prime} \mathrm{W}$ geographic coordinates, with altitude of $365 \mathrm{~m}$. The implantation of sugarcane was held in an area previously occupied with grazing of Brachiária decumbens deployed for over fifteen years.

The evaluation included the harvest of two years, which occurred respectively: sugarcane on October 7th, 2009, and 1st ratoon on June 15th, 2011. In 2010, the harvest was not performed due to low rainfall after harvest of plant cane, as shown in Figure 1. Therefore, it was decided to leave the harvesting of 1st ratoon for 2011.

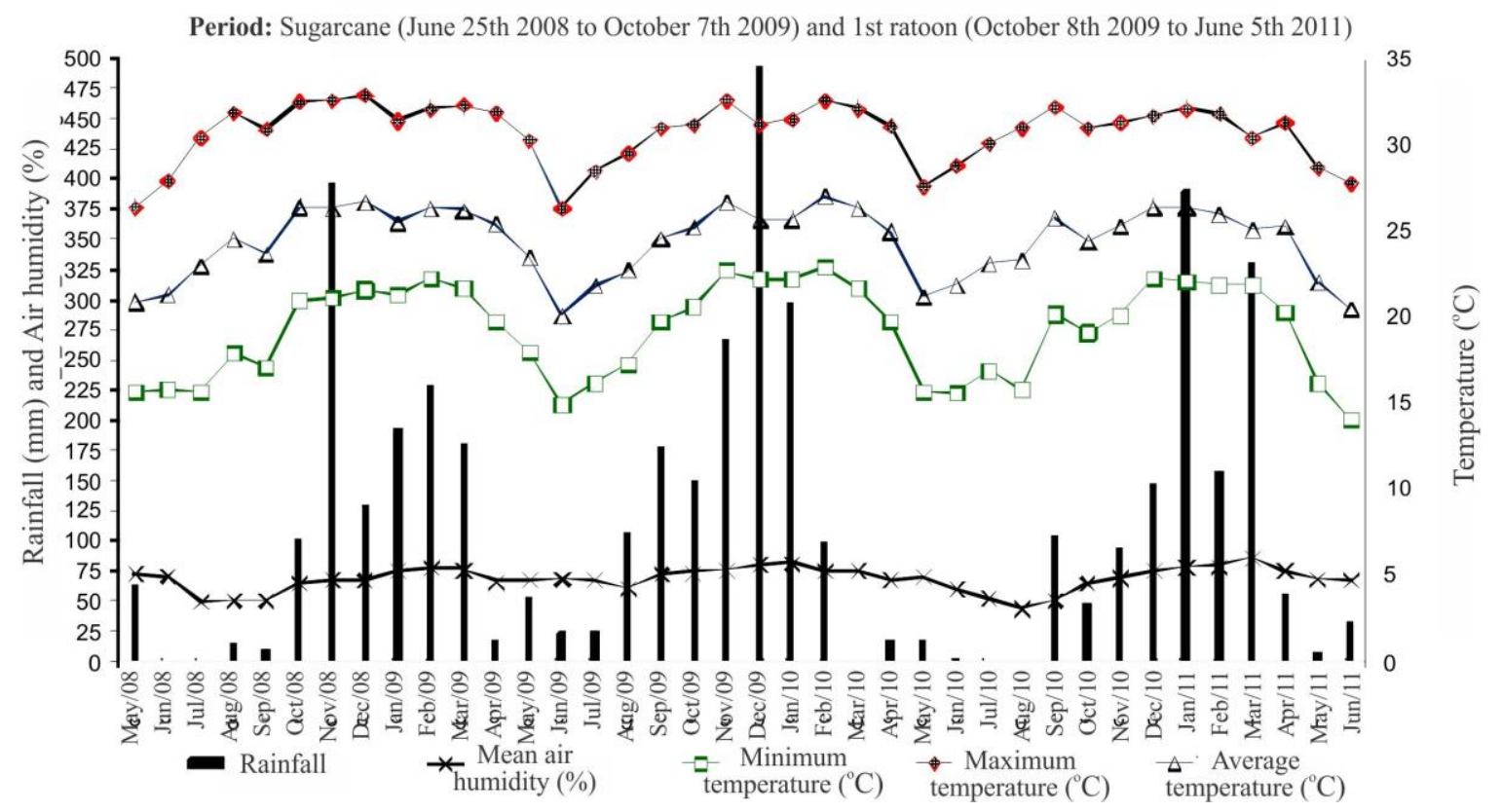

FIGURE 1. Rainfall (mm), air humidity (\%), maximum, minimum and monthly average temperatures $\left({ }^{\circ} \mathrm{C}\right)$.

Source: Meteorological Station located at Vale do Paraná factory, in Suzanápolis city - São Paulo (SP), in Brazil, 18km far from the experimental area.

The climate classification of the region, according to Köppen, is Aw - with average annual rainfall of $1,217 \mathrm{~mm}$ and average annual temperature of $23.7^{\circ} \mathrm{C}$. Figure 1 contains the monthly average values of rainfall $(\mathrm{mm})$, air humidity $(\%)$ and average, maximum and minimum temperatures $\left({ }^{\circ} \mathrm{C}\right)$ of the area during the conduct period of the experiment with sugarcane and 1st ratoon cane. The soil was classified according to EMBRAPA (2006) as dystrophic Ultisol of medium/sandy texture.

Initially, for implantation of sugarcane, desiccation of grassland was held on May 14th 2008, using the herbicides Glyphosate $720 \mathrm{~g} \mathrm{~kg}^{-1}$ i.e. at a dose of $4.0 \mathrm{~L} \mathrm{p.c.} \mathrm{ha}{ }^{-1}$, with a spray volume of $160 \mathrm{~L} \mathrm{ha}^{-1}$.

On May 20th 2008, the soil was sampled with the help of auger on layers 0 to $0.20 \mathrm{~m}, 0.20$ to $0.40 \mathrm{~m}$, and 0.80 to $1.00 \mathrm{~m}$ for particle size analysis, which was performed as EMBRAPA (2011), with the following results: 0 to $0.20 \mathrm{~m}, 88,64,849 ; 0.20$ to $0.40 \mathrm{~m}, 106,61,832 ; 0.80$ to $1.00 \mathrm{~m}, 202$ 57 and $741 \mathrm{~g} \mathrm{~kg}^{-1}$, respectively for the clay, silt and sand values. Soil samples for initial chemical analysis were collected, on the same date, with a screw auger at 20 points distributed in the experimental area, at depths 0.0 to $0.15 \mathrm{~m}, 0.15$ to $0.30 \mathrm{~m}$ and 0.30 to $0.45 \mathrm{~m}$, and in the laboratory they were determined according to the methodology proposed by EMBRAPA (2011), for determining $\mathrm{P}$, the method of resin and $\mathrm{CaCl}_{2}$ solution was used for $\mathrm{pH}$, and the values are presented in Table 1. 
TABLE 1. Soil chemical characterization of the experimental area before liming and the implantation of the experiment, Nova Canãa Paulista-SP, 2008.

\begin{tabular}{|c|c|c|c|c|c|c|c|c|c|c|c|c|c|}
\hline \multirow{2}{*}{ Layers } & \multicolumn{13}{|c|}{ Chemical Analysis } \\
\hline & $\mathrm{P}$ & $\mathrm{pH}$ & $\mathrm{OM}$ & $\mathrm{K}^{+}$ & $\mathrm{Ca}^{+2}$ & $\mathrm{Mg}^{+2}$ & $\mathrm{H}^{+}+\mathrm{Al}^{+3}$ & $\mathrm{Al}^{+3}$ & SB & $\mathrm{CEC}$ & $\mathrm{S}$ & $\mathrm{V}$ & $\mathrm{m}$ \\
\hline m & $\begin{array}{c}\mathrm{mg} \\
\mathrm{dm}^{-3}\end{array}$ & & $\begin{array}{c}\mathrm{mg} \\
\mathrm{dm}^{-3}\end{array}$ & & & & 1 & & & & -- & $\%$ & $\%$ \\
\hline $0.00-0.15$ & 3 & 5.2 & 15 & 2.5 & 7 & 6 & 19 & 0.0 & 15.5 & 34.5 & 2 & 45 & 0 \\
\hline $0.15-0.30$ & 4 & 4.8 & 13 & 2.2 & 10 & 6 & 20 & 2 & 18.2 & 38.2 & 2 & 48 & 11 \\
\hline $0.30-0.45$ & 3 & 5.0 & 11 & 1.4 & 6 & 4 & 33 & 11 & 11.4 & 44.4 & 0 & 26 & 49 \\
\hline
\end{tabular}

$\mathrm{OM}=$ organic matter, $\mathrm{SB}=$ sum of bases, $\mathrm{CEC}=$ cation exchange capacity, $\mathrm{V}$ and $\mathrm{m}=$ bases and aluminum saturation, respectively. Chemical analysis carried out at the Laboratory of Soil Fertility of UNESP/FE.

The experimental design was randomized blocks, in a $3 \times 2$ factorial design with six replications, totaling 36 plots. The treatments consisted of three methods of soil preparation: moldboard plow, chisel plow and heavy harrow, all followed by leveling harrow, and two treatments with $1 \mathrm{t} \mathrm{ha} \mathrm{h}^{-1}$ with and without application of gypsum, for this treatment a corrective distributor cart was used equipped with belt feeder/metering with regulation and turntable.

Operations for deployment of treatments were as follows: distribution of dolomitic lime (2t $\mathrm{ha}^{-1}$ ) in total area (May 20th 2008); the main treatments (moldboard plow, chisel plow and heavy harrow) were implanted on June 3rd 2008, the average depth of tillage were 0.30, 0.26 and 0.25m, respectively; operation with leveling harrow in all treatments, and then secondary treatments were implanted with or without application of gypsum for casting on June 17th 2008, without incorporation.

The variety of sugarcane used was RB92-5354. The planting was done on June 25th 2008 in manual system, spaced $1.5 \mathrm{~m}$ between rows, averaging 15.5 buds $^{-1}$. In planting fertilization, we used 500kg of formula: 06-30-24, at planting, with an average depth of furrowing of 0.49, 0.48 and $0.46 \mathrm{~m}$ for the moldboard plow, heavy harrow and chisel plow, respectively. In phytosanitary control, Fipronil was applied at a dose of $200 \mathrm{~g} \mathrm{ha}^{-1}$ (i.e.), in directed spray on stems in the planting furrow during the operation of furrowing cover. The weed control was carried out with application of diuron + hexazinone $\left(702+264 \mathrm{~g}\right.$ of i.e. $\left.\mathrm{ha}^{-1}\right)$ herbicides in post-emergence of the crop, and it was performed at 40 days after planting and for the 1st ratoon it was performed on January 4th 2010. On the same day, the fertilizer was applied in coverage of 1 st ratoon cane, and $90 \mathrm{~kg} \mathrm{ha}^{-1}$ of $\mathrm{N}$ (urea) and $120 \mathrm{~kg} \mathrm{ha}^{-1}$ of $\mathrm{K}_{2} \mathrm{O}$ (potassium chloride) were applied and incorporated into the soil, with the aid of grower/fertilizer of two lines, carrying simple rods, in a distance of $0.20 \mathrm{~m}$, positioned on the top side of the planting row and at $0.20 \mathrm{~m}$ deep.

Each plot was consisted of six rows of sugarcane of $20 \mathrm{~m}$ long, totaling $180 \mathrm{~m}^{2}$. We used as a useful area two central lines of $5 \mathrm{~m}$ at the plot center area. For the evaluation of the yield, we harvested sugarcane stems through manual cutting, $0.05 \mathrm{~m}$ above ground level, and the lopping of leaves was made the first visible collar, classified as leaf +1 . Then, they were weighed using a scale instrumented with load cell (road scale) and then calculated for tons of stems per hectare (TSH). Following, $10 \mathrm{culms} /$ plot for determination of industrial analysis were separated, and with the results we proceeded to the calculation of the TRS (total recoverable sugar), according to the methodology described by CONSECANA-SP (2006). The number of industrializable stems per meter (NSM) was obtained by averaging the counts of the stems of the two central lines before harvesting. After manual harvesting the stems in useful areas of the parcels, we proceeded to mechanized harvesting of the remaining plots, and the harvester moved throughout the area, including in useful areas already harvested manually. The soil to determine the chemical attributes, $\mathrm{pH}, \mathrm{Ca}^{+2}, \mathrm{Mg}^{+2},\left(\mathrm{H}^{+}+\mathrm{Al}^{+3}\right), \mathrm{Al}^{+3}, \mathrm{~S}-\mathrm{SO}_{4}{ }^{-2}$ and $\mathrm{V} \%$ was collected soon after mechanized harvesting, for both sugarcane (October 7th 2009) and the 1st ratoon (June 15th 2011), in the layers 0.0 to $0.15 \mathrm{~m}, 0.15$ to $0.30 \mathrm{~m}$ and 0.30 to $0.45 \mathrm{~m}$, at the top side and $0.20 \mathrm{~m}$ away from the line of culture. 
Data were subjected to analysis of variance (F Test) and the averages of Tukey test were subjected to comparison of means in two cycles of crops. The computational program SISVAR ${ }^{\circledR}$ was used (FERREIRA, 2003).

\section{RESULTS AND DISCUSSION}

Comparing the chemical attributes values and contents (Table 1), analyzed before the implantation of sugarcane, with those obtained after implantation (Tables 2 and 3), one realizes that they suffered increments, probably due to the effect of limestone, regardless the tillage treatments and use of gypsum.

Table 2 shows the ccontents and values of $\mathrm{pH}, \mathrm{Ca}^{+2}, \mathrm{Mg}^{+2},\left(\mathrm{H}^{+}+\mathrm{Al}^{+3}\right), \mathrm{Al}^{+3}, \mathrm{~S}_{-} \mathrm{SO}_{4}{ }^{-2}$ and $\mathrm{V} \%$ in sugarcanesubjected to treatments of soil preparation, associated with the use or not of gypsum, for the layers of 0.0 to $0.15 \mathrm{~m}, 0.15$ to $0.30 \mathrm{~m}$ and 0.30 to $0.45 \mathrm{~m}$. In the 0.0 to $0.15 \mathrm{~m}$ layer, there has been a significant difference for $\mathrm{pH}$ only for soil tillage systems. The soil with prepared chisel plow showed higher values of $\mathrm{pH}$ in relation to tillage with moldboard plow and heavy harrow. This fact may be explained by the lower soil mobilization by chisel plow and greater concentration of limestone in the soil layer, and because it presents the same characteristic of low solubility and mobility in the soil profile, promoting greater correction of the surface layer, also shown by the higher absolute values of $\mathrm{Ca}^{+2}$ and lower values of $\mathrm{H}^{+}+\mathrm{Al}^{+3}$, these results corroborate those obtained by NETO et al. (2000), who, when working different equipment and implementation of corrective, found that, when the limestone was incorporated with chisel plow and two passes with the leveling harrow, the effects of liming were restricted only to $10 \mathrm{~cm}$ deep.

For the levels of $\mathrm{Mg}^{2+}$ in the 0.0 to $0.15 \mathrm{~m}$ layer, there were significant effects for all treatments evaluated. For tillage, the highest values were for tillage with heavy harrow, due to likely improved mixing and distribution of the limestone with the soil provided by the harrow on that layer, in relation to other equipment. In the treatment with gypsum, there was the lowest content of $\mathrm{Mg}^{2+}$, when compared to treatment without gypsum. CAIRES et al. (2004) verified severe leaching of $\mathrm{Mg}^{2+}$ to the deeper layers with isolated use of gypsum in soil surface. This fact was proven by RAIJ (2008), who attributed the occurrence due to the fact that the use of gypsum causes ion exchange from $\mathrm{Mg}^{2+}$ to $\mathrm{Ca}^{2+}$, solubilizing the $\mathrm{Mg}^{2+}$ in the soil solution, or otherwise, the flow of solution of calcium sulfate descending to the profile will drag the $\mathrm{Mg}^{2+}$ for the lower profile, and there may be significant loss.

The contents of $\mathrm{Al}^{+3}$ and $\mathrm{S}-\mathrm{SO}_{4}{ }^{-2}$ demonstrated the effect of gypsum in this surface layer, with its use there was an increase in the content of $\mathrm{S}_{-} \mathrm{SO}_{4}{ }^{-2}$ and decrease of $\mathrm{Al}^{+3}$. According to SOUSA AND LOBATO (2004), by applying correctives in the soil, such as limestone and gypsum, there is the movement of cations into the subsurface, the calcium and magnesium contents increase, causing a reduction in the content of toxic aluminum and improving the soil environment for the roots to develop.

In 0.15 to $0.30 \mathrm{~m}$ layer (Table 2), it is found higher values of $\mathrm{pH}$ in the treatment with moldboard plow in relation to the chisel plow. This may have been due to the greater sod inversion of the surface layer and deeper lime incorporation promoted by moldboard plow, and in this layer the preparation with moldboard gave lower values of potential acidity and higher values of $\mathrm{Ca}^{+2}$ and base saturation. 
TABLE 2. Soil chemical attributes in layers 0.0 to $0.15 \mathrm{~m}, 0.15$ to $0.30 \mathrm{~m}$ and 0.30 to $0.45 \mathrm{~m}$, in soil tillage systems, associated with application of gypsum, evaluated 462 days after planting, Plant cane, 2009.

\begin{tabular}{|c|c|c|c|c|c|c|c|}
\hline & pH & $\mathbf{C a}^{+2}$ & $\mathrm{Mg}^{+2}$ & $\mathbf{H}^{+}+\mathbf{A l}^{+3}$ & $\mathrm{Al}^{+3}$ & $\mathrm{~S}_{-\mathrm{SO}_{4}}^{-2}$ & $\mathbf{V}$ \\
\hline & $\mathrm{CaCl}$ & & &.. $\mathrm{mmol}_{\mathrm{c}} \mathrm{dm}^{-}$ & & ........... & $\%$ \\
\hline Preparation & \multicolumn{7}{|c|}{$0.0-0.15 \mathrm{~m}$} \\
\hline Moldboard & ${ }^{(1)} 5.07 \mathrm{~b}$ & 15.83 & $6.00 \mathrm{~b}$ & $18.00 \mathrm{a}$ & ${ }^{(2)} 0.91$ & 3.75 & 56.00 \\
\hline Chisel & $5.68 \mathrm{a}$ & 21.42 & $7.91 \mathrm{ba}$ & $14.42 \mathrm{~b}$ & 0.75 & 4.08 & 60.00 \\
\hline Heavy harrow & $5.13 \mathrm{~b}$ & 17.50 & $12.50 \mathrm{a}$ & $16.42 \mathrm{ab}$ & 0.82 & 4.58 & 67.08 \\
\hline \multicolumn{8}{|l|}{ Gypsum } \\
\hline With gypsum & 5.38 & 20.22 & $6.88 \mathrm{~b}$ & 15.94 & $0.74 \mathrm{~b}$ & $6.28 \mathrm{a}$ & 63.33 \\
\hline Without gypsum & 5.31 & 17.28 & $10.72 \mathrm{a}$ & 16.61 & $0.92 \mathrm{a}$ & $2.00 \mathrm{~b}$ & 59.28 \\
\hline \multicolumn{8}{|l|}{ F Test } \\
\hline Preparation (P) & $5.32 *$ & $1.65^{\mathrm{ns}}$ & $4.88^{*}$ & $3.47 *$ & $1.20^{\mathrm{ns}}$ & $2.64^{\mathrm{ns}}$ & $2.76^{\mathrm{ns}}$ \\
\hline Gypsum (G) & $0.25^{\mathrm{ns}}$ & $2.35^{\mathrm{ns}}$ & $4.82 *$ & $0.36^{\mathrm{ns}}$ & $4.92 *$ & $205.58 * *$ & $1.10^{\mathrm{ns}}$ \\
\hline $\mathrm{P} * \mathrm{G}$ & $1.47^{\mathrm{ns}}$ & $1.58^{\mathrm{ns}}$ & $1.43^{\mathrm{ns}}$ & $0.95^{\mathrm{ns}}$ & $0.40^{\mathrm{ns}}$ & $0.971^{\mathrm{ns}}$ & $1.23^{\mathrm{ns}}$ \\
\hline LSD Preparation & 0.48 & 7.86 & 5.33 & 3.40 & 0.25 & 0.91 & 11.78 \\
\hline LSD Gypsum & 0.32 & 5.30 & 3.59 & 2.29 & 0.17 & 0.61 & 7.95 \\
\hline CV (\%) & 8.79 & 42.31 & 59.49 & 20.51 & 29.61 & 21.63 & 18.90 \\
\hline Preparation & \multicolumn{7}{|c|}{$0.15-0.30 \mathrm{~m}$} \\
\hline Moldboard & $5.63 \mathrm{a}$ & $18.75 \mathrm{a}$ & 8.83 & $14.17 \mathrm{~b}$ & ${ }^{(2)} 0.75$ & 3.42 & $65.33 \mathrm{a}$ \\
\hline Chisel & $5.19 \mathrm{~b}$ & $14.25 \mathrm{~b}$ & 7.15 & $17.17 \mathrm{a}$ & 0.89 & 3.33 & $56.00 \mathrm{~b}$ \\
\hline Heavy harrow & $5.37 \mathrm{ab}$ & $14.17 \mathrm{~b}$ & 7.17 & $15.50 \mathrm{ab}$ & 0.75 & 3.33 & $59.00 \mathrm{ab}$ \\
\hline \multicolumn{8}{|l|}{ Gypsum } \\
\hline With gypsum & 5.38 & 16.89 & 8.06 & 15.94 & 0.76 & $4.17 \mathrm{a}$ & 60.61 \\
\hline Without gypsum & 5.41 & 14.56 & 8.39 & 15.27 & 0.83 & $2.55 \mathrm{~b}$ & 59.11 \\
\hline \multicolumn{8}{|l|}{ F Test } \\
\hline Preparation $(\mathrm{P})$ & $3.27 *$ & $6.08 *$ & $1.57^{\mathrm{ns}}$ & $3.60 *$ & $1.28^{\mathrm{ns}}$ & $0.04^{\mathrm{ns}}$ & $4.71 *$ \\
\hline Gypsum (G) & $0.04^{\mathrm{ns}}$ & $3.61^{\mathrm{ns}}$ & $2.26^{\mathrm{ns}}$ & $0.53^{\mathrm{ns}}$ & $0.72^{\mathrm{ns}}$ & $36.44 *$ & $0.16^{\mathrm{ns}}$ \\
\hline $\mathrm{P}^{*} \mathrm{G}$ & $1.56^{\mathrm{ns}}$ & $2.22^{\mathrm{ns}}$ & $1.32^{\mathrm{ns}}$ & $1.11^{\mathrm{ns}}$ & $0.96^{\mathrm{ns}}$ & $0.30^{\mathrm{ns}}$ & $2.53^{\mathrm{ns}}$ \\
\hline LSD Preparation & 0.43 & 3.75 & 2.21 & 2.79 & 0.26 & 0.81 & 7.73 \\
\hline LSD Gypsum & 0.29 & 2.53 & 1.83 & 1.88 & 0.17 & 0.55 & 5.22 \\
\hline CV (\%) & 7.89 & 23.44 & 34.44 & 17.57 & 31.92 & 23.82 & 12.65 \\
\hline Preparation & \multicolumn{7}{|c|}{$0.30-0.45 \mathrm{~m}$} \\
\hline Moldboard & 5.20 & 13.92 & $6.67 \mathrm{a}$ & 16.83 & $\left({ }^{(2)} 0.75\right.$ & $3.58 \mathrm{~b}$ & 55.50 \\
\hline Chisel & 4.89 & 13.00 & $4.75 \mathrm{~b}$ & 18.25 & 0.99 & $4.33 \mathrm{ab}$ & 50.00 \\
\hline Heavy harrow & 5.11 & 13.75 & $6.58 \mathrm{ab}$ & 17.67 & 0.91 & $4.67 \mathrm{a}$ & 54.08 \\
\hline \multicolumn{8}{|l|}{ Gypsum } \\
\hline With gypsum & 5.05 & $14.78 \mathrm{a}$ & 6.33 & 18.50 & $0.76 \mathrm{~b}$ & $6.00 \mathrm{a}$ & 53.94 \\
\hline Without gypsum & 5.08 & $12.33 \mathrm{~b}$ & 5.67 & 17.67 & $1.00 \mathrm{a}$ & $2.39 \mathrm{~b}$ & 51.14 \\
\hline \multicolumn{8}{|l|}{ F Test } \\
\hline Preparation $(\mathrm{P})$ & $2.87^{\mathrm{ns}}$ & $0.43^{\mathrm{ns}}$ & $4.06^{*}$ & $0.86^{\mathrm{ns}}$ & $2.54^{\mathrm{ns}}$ & $4.61^{*}$ & $2.17^{\mathrm{ns}}$ \\
\hline Gypsum (G) & $0.09^{\mathrm{ns}}$ & $8.00 *$ & $1.15^{\mathrm{ns}}$ & $2.26^{\mathrm{ns}}$ & $6.87 *$ & $146.50 *$ & $0.45^{\mathrm{ns}}$ \\
\hline $\mathrm{P}^{*} \mathrm{G}$ & $0.49^{\mathrm{ns}}$ & $1.49^{\mathrm{ns}}$ & $0.22^{\mathrm{ns}}$ & $1.28^{\mathrm{ns}}$ & $3.09^{\mathrm{ns}}$ & $2.12^{\mathrm{ns}}$ & $0.32^{\mathrm{ns}}$ \\
\hline LSD Preparation & 0.32 & 2.64 & 1.89 & 2.71 & 0.28 & 0.91 & 6.84 \\
\hline LSD Gypsum & 0.22 & 1.78 & 1.29 & 1.83 & 0.19 & 0.61 & 4.61 \\
\hline CV $(\%)$ & 9.69 & 19.13 & 31.03 & 15.16 & 31.43 & 21.34 & 12.64 \\
\hline
\end{tabular}


As occurred in the surface layer, the use of gypsum to the layer 0.15 to $0.30 \mathrm{~m}$ showed values of $\mathrm{S}-\mathrm{SO}_{4}{ }^{-2}$ significantly higher than those found in the treatment without gypsum, however, other attributes evaluated were not affected by the use of gypsum. According to DIAS AND ROSSETO (2006), the gypsum does not correct acidity, but, because it has higher solubility compared to limestone, it is a great source of calcium and sulfur for nutrition of sugarcane, in addition to improving fertility, by allowing a greater intake of calcium and other cations, in depth of the soil.

No significant differences occurred in the content of $\mathrm{Ca}^{+2}$ in layers 0.0 to $0.15 \mathrm{~m}$ and 0.15 to $0.30 \mathrm{~m}$ (Table 2) due to the use of gypsum, however, in the 0.30 to $0.45 \mathrm{~m}$ layer, the addition of gypsum increased the contents of $\mathrm{Ca}^{+2}$. This depth effect is due to the supply of $\mathrm{Ca}^{+2}$ to the soil by application of limestone and gypsum in the first layer, potentiating by higher solubility and dissociation of $\mathrm{CaSO}_{4}{ }^{0}$ and drag of exchangeable bases $\left(\mathrm{Ca}^{+2}\right)$ by the sulfate ion $\left(\mathrm{SO}_{4}{ }^{-2}\right)$. This result corroborates those of $\backslash$, who in their research found that the application of the mineral gypsum increased the content of exchangeable calcium in the subsurface, and consequently reduced the contents of exchangeable aluminum and saturation by aluminum.

In the 0.30 to $0.45 \mathrm{~m}$ layer, the concentration of $\mathrm{Mg}^{2+}$ provided by chisel plow were lower than those obtained with moldboard plow and heavy harrow. However, in the treatment with gypsum, there was increase in contents of $\mathrm{Ca}^{2+}$ and $\mathrm{S}_{-} \mathrm{SO}_{4}{ }^{-2}$ and reduction of $\mathrm{Al}^{+3}$. The results presented here are corroborated by the theory of SOUZA AND LOBATO (2004), who said that, when the arable layer receives limestone and phosphate, the gypsum, to dissolve in water, will infiltrate in the soil, passing through this layer and getting trapped in the subsurface layers until 60 or $80 \mathrm{~cm}$.

Table 3 contains the values of $\mathrm{pH}, \mathrm{Ca}^{+2}, \mathrm{Mg}^{+2},\left(\mathrm{H}^{+}+\mathrm{Al}^{+3}\right), \mathrm{Al}^{+3}, \mathrm{~S}_{-} \mathrm{SO}_{4}{ }^{-2} \mathrm{e} \mathrm{V} \%$, in 1 st ratoon cane, in layers 0.0 to $0.15 \mathrm{~m}, 0.15$ to $0.30 \mathrm{~m}$ and 0.30 to $0.45 \mathrm{~m}$. It is observed that there was residual effect of gypsum in 1 st ratoon cane, because this treatment provided higher contents of $\mathrm{Ca}^{+2}, \mathrm{~S}_{-} \mathrm{SO}_{4}{ }^{-}$ 2 and $\mathrm{V} \%$ and reduction of $\mathrm{Al}^{+3}$ in the three layers evaluated. These effects resemble those observed by several authors, CARVALHO et al. (2013), when evaluating application of agricultural gypsum and vinasse in the culture of sugarcane, found significant increments of $5.3 \mathrm{mmolc} \mathrm{dm}{ }^{-3}$ in relation to the non-application of gypsum, effect expected by the release of the cation from the dissociation of $\mathrm{CaSO}_{4} \cdot 2 \mathrm{H}_{2} \mathrm{O}$ in the soil solution, this increase in $\mathrm{Ca}^{2+}$ content determined the elevation of the saturation by bases (V) to 47\%, and SALDANHA et al. (2007) concluded in their work that the mineral gypsum increased the content of exchangeable calcium and the values of bases saturation in the subsurface, and consequently reduced levels of exchangeable aluminum and aluminum saturation.

The same effects were observed by CARVALHO et al. (2013) in their study, who, using gypsum, detected increase in the levels of calcium and elevation of descending bases saturation and increase in the content of $\mathrm{Ca}^{+2}$ and higher percentage of roots of sugarcane in the subsurface. The tillage treatments did not show behavior that denote its residual effects on the studied attributes, with the exception of the contents of $\mathrm{Ca}^{+2}$, where the highest values were found in the chisel plow tillage treatment in the layer 0.30 to $0.45 \mathrm{~m}$, showing that the vertical soil disruption facilitated the descending movement of calcium. The fact that the soil tillage treatments did not show significant differences in soil chemical attributes in the 1st ratoon cane, among other factors, may be related to the sandy texture of the soil, which facilitated the leaching of bases in depth. 
TABLE 3. Soil chemical attributes in layers 0.0 to $0.15 \mathrm{~m}, 0.15$ to $0.30 \mathrm{~m}$ and 0.30 to $0.45 \mathrm{~m}$ in soil tillage systems, associated with application of gypsum, evaluated 610 days after the cutting, 1st ratoon cane, 2011.

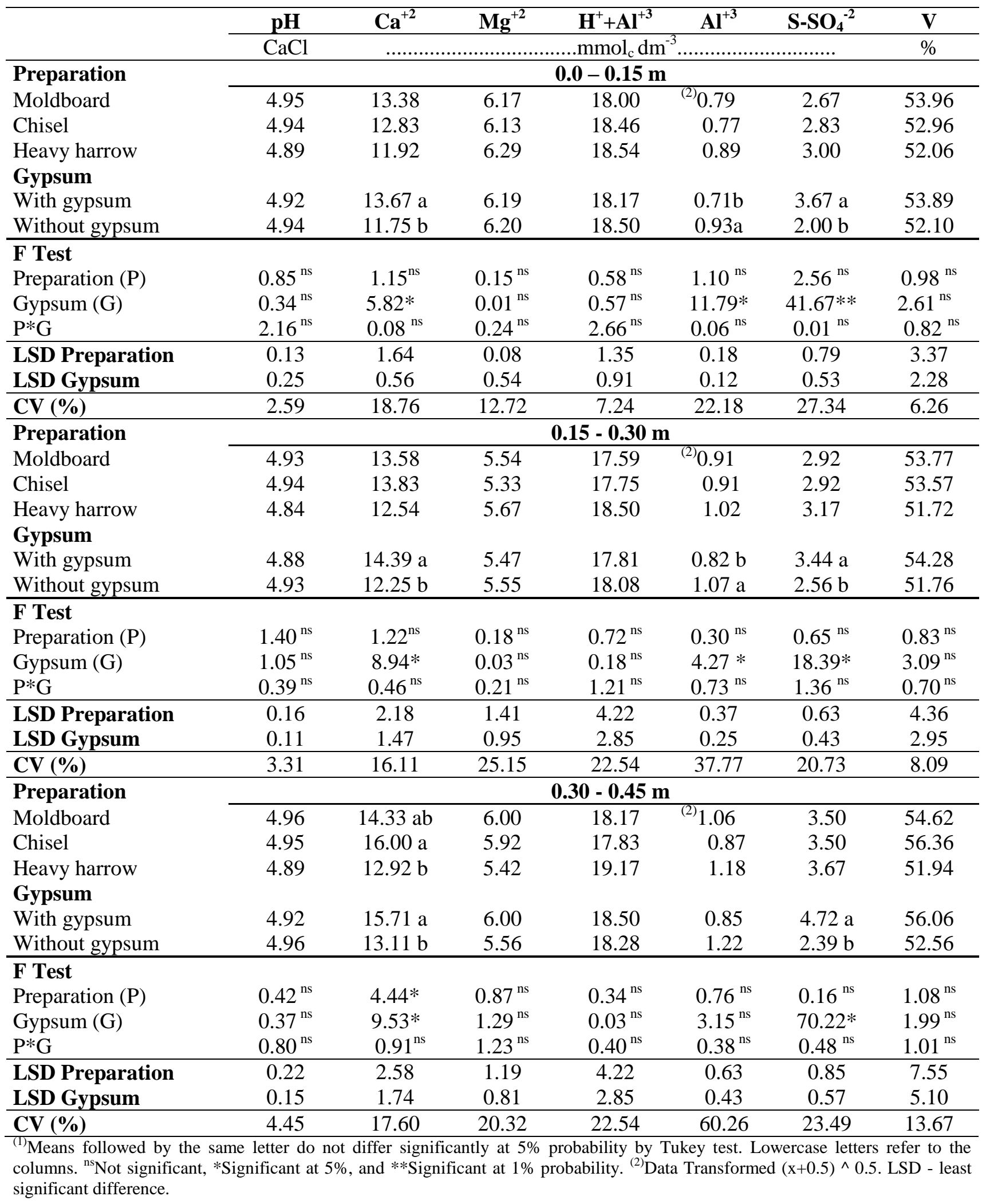

Data from yield of stems of sugarcane and 1st ratoon are presented in Table 4. In plant cane, significant differences were observed only for TRS. The other variables showed no significant differences among the treatments studied. 
The use of gypsum led to higher values of TRS, demonstrating that it influenced positively the final quality of harvested cane, possibly due to better soil conditioning on the subsurface, and because of this it may have favored larger deep of root growth and soil volume explored, increasing thereby the absorption of water and nutrients.

According to TASSO JUNIOR et al. (2007), the TRS represents all sugars as invert sugars, which will be recovered in the industry, and we must highlight that the current cane payment is based on this parameter. Thus, the greater the amount of TRS $\left(\mathrm{kg} \mathrm{t}^{-1}\right)$, the higher will be the yield of sugar and alcohol. RIPOLI \& RIPOLI (2004) cite indicative values of quality for sugarcane, indicating that the TRS (total recoverable sugar) should be $>150 \mathrm{~kg} \mathrm{t}^{-1}$. It appears that the values presented in Table 4, for all treatments, in the two seasons analyzed, are close to or higher than the indicated.

In plant cane, the statistical difference with the highest TRS value was with application of gypsum, with a gain of $4.75 \mathrm{~kg}$ of TRS per ton of sugarcane harvested. Considering the yield of $90.22 \mathrm{t} \mathrm{ha}^{-1}$ for the same treatment, we obtain $428.54 \mathrm{~kg} \mathrm{ha}^{-1}$ of TRS more than the in the absence of gypsum.

TABLE 4. Averages for the number of stems per meter (NSM), yield tons of stems per hectare (TSH) and total recoverable sugar (TRS), in sugarcane and 1st ratoon cane, according to soil tillage versus, with and without gypsum. Nova Canãa Paulista-SP.

\begin{tabular}{|c|c|c|c|c|c|c|}
\hline \multirow{3}{*}{ Treatments } & \multicolumn{3}{|c|}{ SUGARCANE - 2009} & \multicolumn{3}{|c|}{ 1st ratoon - 2011} \\
\hline & NSM & TSH & TRS & NSM & TSH & TRS \\
\hline & $(\mathrm{m})$ & $\left(\mathrm{t} \mathrm{ha}^{-1}\right)$ & $\left(\mathrm{kg} \mathrm{t}^{-1}\right)$ & $(\mathrm{m})$ & $\left(\mathrm{t} \mathrm{ha}^{-1}\right)$ & $\left(\mathrm{kg} \mathrm{t}^{-1}\right)$ \\
\hline \multicolumn{7}{|l|}{ Soil tillage } \\
\hline Moldboard & 9.37 & 89.89 & 154.42 & 9.40 & 77.44 & 149.03 \\
\hline Chisel & 9.27 & 90.22 & 151.52 & 9.14 & 73.34 & 153.58 \\
\hline Heavy harrow & 9.11 & 83.72 & 149.17 & 9.12 & 74.33 & 151.28 \\
\hline \multicolumn{7}{|l|}{ Gypsum } \\
\hline With gypsum & 9.41 & 89.78 & $154.08 \mathrm{a}$ & 9.31 & $79.63 \mathrm{a}$ & 153.68 \\
\hline Without gypsum & 9.08 & 86.11 & $149.33 \mathrm{~b}$ & 9.33 & $70.45 \mathrm{~b}$ & 148.90 \\
\hline \multicolumn{7}{|l|}{ F Test } \\
\hline Preparation $(\mathrm{P})$ & $0.23^{\mathrm{ns}}$ & $1.51^{\mathrm{ns}}$ & $2.60^{\mathrm{ns}}$ & $0.34^{\mathrm{ns}}$ & $1.49^{\mathrm{ns}}$ & 1.12 \\
\hline Gypsum (G) & $1.08^{\mathrm{ns}}$ & $1.14^{\mathrm{ns}}$ & $6.33^{*}$ & $0.01^{\mathrm{ns}}$ & $20.59^{*}$ & 3.71 \\
\hline $\mathrm{P} * \mathrm{G}$ & $0.21^{\mathrm{ns}}$ & $1.94^{\mathrm{ns}}$ & $1.76^{\mathrm{ns}}$ & $2.30^{\mathrm{ns}}$ & $1.01^{\mathrm{ns}}$ & 0.55 \\
\hline LSD Preparation & 0.84 & 9.07 & 3.72 & 0.81 & 5.33 & 4.92 \\
\hline LSD Gypsum & 0.55 & 5.88 & 5.74 & 0.52 & 3.46 & 7.57 \\
\hline C.V. (\%) & 10.36 & 11.74 & 3.88 & 9.89 & 8.09 & 3.88 \\
\hline
\end{tabular}

For 1st ratoon cane, there were significant differences for yield in tons of stems per hectare (TSH), however, there were higher values given by treatment with gypsum, with increase in yield of $9 \mathrm{tha}^{-1}$. The fact that the result of TSH was favorable with use of gypsum may be explained by the benefits provided by this input in the subsurface, also promoting likely improvement in deepening in root growth, with chances of greater absorption of water during periods of lower or higher water deficit, as occurred in this study in the period from March to August/2010 (Figure 1). MORELLI et al. (1992) also found positive results of stem yield when they used gypsum and gypsum associated with limestone at rates of $0,2,4$ and $6 \mathrm{t} \mathrm{ha}^{-1}$ in sugarcane and $1 \mathrm{st}, 2$ nd and 3rd ratoon cane, in an alic dark Red Latosol of medium texture. 
The methods of tillage did not influence the productivity of sugarcane in the two seasons studied, probably due to the fact that it was a sandy soil, without limiting compression at the beginning of the experiment.

\section{CONCLUSIONS}

The presented results confirmed the initial hypothesis that in sandy soils, without limiting compression and with the use of agricultural gypsum, there was no need for deep tillage, because the differences in soil chemical attributes due to tillage methods occurred in the sugarcane did not last until the harvest of 1 st ratoon and did not affect the yield.

The gypsum application provided higher values of TRS and yield of TSH, to sugarcane and 1st ratoon cane, respectively, confirming the initial hypothesis.

\section{REFERENCES}

CAIRES, E.F.; KUSMAN, M.T.; BARTH, G.; GARBUIO, F.J.; PADILHA, J.M. Alterações químicas do solo e resposta do milho à calagem e aplicação de gesso. Revista Brasileira de Ciência do Solo, Viçosa-MG, v. 28, p.125-136, 2004.

CARVALHO, J.M.; ANDREOTTI, M.; BUZETTI, S.; CARVALHO, M.P. Produtividade de cana soca sem queima em função do uso de gesso e vinhaça. Pesquisa Agropecuária Troprical, Goiania, v. 43, n. 1, p. 1-9, 2013.

CONAB. Companhia Nacional de Abastecimento. Acompanhamento de safra brasileira: cana-deaçúcar, segundo levantamento, Agosto. Brasília: Conab, 2011. p. 20.

CONSECANA - Conselho dos Produtores de Cana-De-Açúcar, Açúcar e Álcool do Estado de São Paulo. Manual de instruções. 5. ed. Piracicaba: Consecana, 2006. 112 p.

DIAS, F.L.F; ROSSETO, R. Calagem e Adubação da Cana-de-acúcar. In: SEGATO, S. V.; PINTO, A. S.; JENDIROBA, E.; NÓBREGA, J. C. M. Atualização em produção de cana-de-açúcar. Piracicaba: CP 2, 2006. p. 107-119.

EMBRAPA. Empresa Brasileira de Pesquisa Agropecuária. Sistema brasileiro de classificação de solos. Rio de Janeiro: CNPS, 2006. 306 p.

EMBRAPA. Empresa Brasileira de Pesquisa Agropecuária. Manual de métodos de análises de solo. Rio de Janeiro, 2011. 230p.

FERREIRA, D. F. Sisvar: versão 4.2. Lavras: DEX/UFLA, 2003.

KICHLER, C. M. et al. Spatially monitoring tractor performance to evaluate energy equirements of variable depth tillage and implement selection. Minneapolis: American Society of Agricutural and Biological Engineers, 2007. (Paper, 071028).

MICHEL JUNIOR, J. A.; FORNSTROM, K. J.; BORELLI, J. Energy requirements of two tillage systems for irrigated sugarbeets, dry beans and corn. Transactions of the ASAE, St. Joseph, v. 28, n. 6, p. 1731- 1735, 1985.

MORELLI, J.L.; DALBEN, A.E.; ALMEIDA, J.O.C.; DEMATTÊ, J.L.I. Calcário e gesso na produtividade da cana-de-açúcar e nas características químicas de um latossolo de textura médio alíco. Revista Brasileira de Ciência do Solo, Viçosa-MG, v.16, p.187- 194, 1992.

NETO, P. H. W.; CAIRES, E.F.; JUSTINO, A.; DIAS, J. Correção da acidez do solo em função de modos de incorporação de calcário. Ciência Rural, Santa Maria, v. 30, n. 2, p. 257-261, 2000.

QUAGGIO, J.A. Acidez e calagem em solos tropicais. Campinas: Instituto Agronômico, 2000. 111 p.

RAIJ, B. van. Gesso na agricultura. Campinas: Instituto Agronômico, 2008. 233 p. 
RIPOLI, T.C.C.; RIPOLI, M.L.C. Biomassa de cana-de-açúcar: colheita, energia e ambiente. Piracicaba: Ed.dos autores, 2004. 309 p.

SALDANHA, E.C.M.; ROCHA, A.T.; OLIVEIRA, E.C.A.; NASCIMENTO, W.A.; FREIRE, F.J. Uso do gesso mineral em latossolo cultivado com cana de açúcar. Revista Caatinga. Mossoró. v.20, n.1, p. 36-42, 2007.

SALVADOR, N.; MION, R.L.; BENEZ, S.H.; VILIOTTI, C.A. Estudo da demanda energética e desagregação do solo em diferentes sequências operacionais de preparo periódico. Revista Ciência Agronômica, Fortaleza, v.41, n.2, p. 231-236, 2010.

SALVADOR, N.; BENEZ, S. H.; MION, R. L. Demanda energética em diferentes sistemas de preparo periódico do solo antes e depois da subsolagem. Revista Ciência Agronômica,Fortaleza, v. 39, n. 3, p. 378-383, 2008.

SOUSA, D. M. G. de; LOBATO, E. Cerrado: correção do solo e adubação. 2.ed. Brasília, DF: Embrapa Informação Tecnológica, 2004. 416 p.

TASSO JUNIOR, L.C.; MARQUES, M.O.; FRANCO, A.; NOGUEIRA, A; G. NOBILE, F. de; CAMILOTTI, F.; SILVA, A.R. da. Produtividade e qualidade de cana-de-açúcar cultivada em solo tratado com lodo de esgoto, vinhaça e adubos minerais. Engenharia Agrícola, Jaboticabal, v. 27, n. 1, p, 276-283, 2007. 